\title{
CD27 expression discriminates porcine T helper cells with functionally distinct properties
}

\author{
Katharina Reutner ${ }^{1}$, Judith Leitner ${ }^{2}$, Andrea Müllebner ${ }^{3}$, Andrea Ladinig ${ }^{4}$, Sabine E Essler ${ }^{1}$, J Catharina Duvigneau ${ }^{3}$, \\ Mathias Ritzmann ${ }^{4}$, Peter Steinberger ${ }^{2}$, Armin Saalmüller ${ }^{1}$ and Wilhelm Gerner ${ }^{1 *}$
}

\begin{abstract}
Differentiation of porcine T helper cells is still poorly investigated, partly due to a lack of monoclonal antibodies (mAbs) specific for molecules involved in this process. Recently, we identified a mAb specific for porcine CD27 and

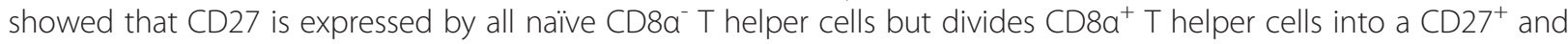
a CD27 subset. In the present study, detailed phenotypical and functional analyses of these T-helper cell subpopulations were performed. Naïve $\mathrm{CD} 8 \mathrm{a}^{-} \mathrm{CD} 27^{+} \mathrm{T}$ helper cells predominantly resided in various lymph nodes, whereas higher proportions of $\mathrm{CD} 8 \mathrm{a}^{+} \mathrm{CD} 27^{+}$and $\mathrm{CD} 8 \mathrm{a}^{+} \mathrm{CD} 27^{-} \mathrm{T}$ helper cells were found in blood, spleen and liver.

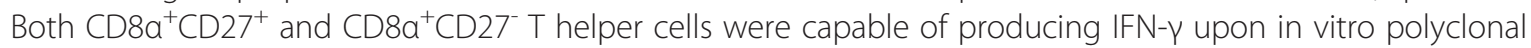
stimulation and antigen-specific restimulation. Experiments with sorted $\mathrm{CD} 8 \mathrm{a}^{-} \mathrm{CD} 27^{+}, \mathrm{CD} 8 \mathrm{a}^{+} \mathrm{CD} 27^{+}$and $\mathrm{CD} 8 \mathrm{a}^{+} \mathrm{CD} 27^{-}$ T-helper cell subsets following polyclonal stimulation revealed the lowest proliferative response but the highest ability for IFN- $\gamma$ and TNF-a production in the $\mathrm{CD} \mathrm{a}^{+} \mathrm{CD} 27^{-}$subset. Therefore, these cells resembled terminally differentiated effector memory cells as described in human. This was supported by analyses of CCR7 and CD62L expression. CD8a ${ }^{+} \mathrm{CD} 27^{-} \mathrm{T}$ helper cells were mostly CCR7 ${ }^{-}$and had considerably reduced CD62L mRNA levels. In contrast, expression of both homing-receptors was increased on $\mathrm{CD} 8 \mathrm{a}^{+} \mathrm{CD} 27^{+} \mathrm{T}$ helper cells, which also had a proliferation rate similar to naïve $\mathrm{CD} 8 \mathrm{a}^{-} \mathrm{CD} 27^{+} \mathrm{T}$ helper cells and showed intermediate levels of cytokine production. Therefore, similar to human, $\mathrm{CD} 8 \mathrm{a}^{+} \mathrm{CD} 27^{+} \mathrm{T}$ helper cells displayed a phenotype and functional properties of central memory cells.
\end{abstract}

\section{Introduction}

A peculiarity of porcine $\mathrm{T}$ helper cells is the expression of $\mathrm{CD} 8 \alpha$ on a substantial proportion of these cells in blood and secondary lymphatic organs $[1,2]$. In vitro stimulation by superantigens or mixed leukocyte reactions causes an up-regulation of $\mathrm{CD} 8 \alpha$ expression on porcine $\mathrm{T}$ helper cells [1,3], and it was reported that $\mathrm{CD} 8 \alpha^{+} \mathrm{T}$ helper cells proliferate in response to stimulation with recall antigen [4-6]. Therefore, CD8 $\alpha$ expression is perceived as a marker for activated and memory $\mathrm{T}$ helper cells, whereas a $\mathrm{CD} 4{ }^{+} \mathrm{CD} 8 \alpha^{-}$phenotype is considered to define naïve $\mathrm{T}$ helper cells [3]. In addition to CD8 $\alpha$, the expression of CD45RC and swine leukocyte antigen-DR (SLA-DR) was investigated in previous studies to identify different memory stages of $\mathrm{CD} 8 \alpha^{+} \mathrm{T}$ helper cells. Differentiation from naïve $\mathrm{CD} 8 \alpha^{-}$to memory $\mathrm{CD} 8 \alpha^{+} \mathrm{T}$ helper cells was

\footnotetext{
* Correspondence: wilhelm.gerner@vetmeduni.ac.at

${ }^{1}$ Institute of Immunology, Department of Pathobiology, University of

Veterinary Medicine Vienna, Veterinärplatz 1, Vienna 1210, Austria

Full list of author information is available at the end of the article
}

described to be accompanied by a loss of CD45RC and an increase in SLA-DR expression [3]. However, an accurate discrimination of functionally distinct $\mathrm{T}$ helper cells following antigen contact has remained unsuccessful so far [7].

In human and mouse, differentiation of $\mathrm{T}$ helper cells is commonly defined by i) the expression of receptors for lymph node homing, ii) the expression of co-stimulatory molecules and iii) the capability to produce certain cytokines. With regard to the lymph node homing receptors CD62L and CCR7, two functionally distinct memory subsets have been defined: $\mathrm{CD}^{2} 2 \mathrm{~L}^{+} \mathrm{CCR} 7^{+}$central memory and CD62L ${ }^{-}$CCR7 ${ }^{-}$effector memory $\mathrm{T}$ helper cells. Central memory $\mathrm{T}$ helper cells proliferate and produce IL-2, whereas effector memory $\mathrm{T}$ helper cells secrete high amounts of cytokines such as IFN- $\gamma$ and IL-4 upon stimulation [8]. Regarding the expression of co-stimulatory molecules, $\mathrm{T}$ helper cells initially express CD27, a member of the tumor necrosis factor receptor (TNFR) family, which contributes to proliferation, survival and 
cytokine production. During T-cell differentiation, CD27 expression undergoes down-regulation and is finally lost on terminally differentiated effector cells $[9,10]$.

In a recent study, we could identify Swine Workshop Cluster 2 as porcine CD27 by the use of a porcine retroviral complementary DNA (cDNA) expression library and the monoclonal antibody (mAb) b30c7 [11]. Regarding the expression of CD27 on porcine $\mathrm{T}$ helper cells, it was demonstrated in this study that CD27 is expressed by all naive $C D 8 \alpha^{-} \mathrm{T}$ helper cells but classifies $\mathrm{CD} 8 \alpha^{+} \mathrm{T}$ helper cells into a CD27 $7^{+}$and a CD27 $7^{-}$subset. Accordingly, due to the presence of $C D 27^{-} \mathrm{T}$ helper cells only within the $C D 8 \alpha^{+}$population, we hypothesized that $\mathrm{CD} 27^{+}$and CD27 $\mathrm{T}$ helper cells represent separate differentiation stages of porcine T-helper cell development following antigen contact.

Therefore, in the present study, we addressed functional as well as more detailed phenotypical characteristics of CD27-defined T-helper cell subsets in swine. Co-expression of CD4, CD8 $\alpha$, CD27, CD45RC and SLA-DR was analysed within blood, secondary lymphoid organs and liver by flow cytometry (FCM). Functional studies revealed differences in the proliferative capacity and production of the cytokines IFN- $\gamma$, TNF- $\alpha$ and IL-2. CD8 $\alpha^{+}$CD27 ${ }^{-} \mathrm{T}$ helper cells showed the lowest proliferation but were superior in IFN- $\gamma$ and TNF- $\alpha$ release, therefore, resembling effector memory $\mathrm{T}$ cells in human. CD $8 \alpha^{+} \mathrm{CD} 27^{+} \mathrm{T}$ helper cells showed a proliferation similar to the naïve $\mathrm{CD} 8 \alpha^{-} \mathrm{CD} 27^{+}$fraction and intermediate cytokine production, i.e. attributes reminiscent of central memory $\mathrm{T}$ helper cells. This functional allocation was confirmed by phenotypic analyses of the adhesion molecule CD62L as well as the chemokine receptors CCR7 and CX3CR1.

\section{Materials and methods \\ Animals and cell isolation}

Blood, spleen and mediastinal lymph nodes of healthy six-month old pigs were obtained from an abattoir, where animals were subjected to electric high voltage anaesthesia followed by exsanguination. This procedure is in accordance to the Austrian Animal Welfare Slaughter Regulation. For detailed phenotypical analyses within blood, spleen, mediastinal, bronchial and mesenteric lymph nodes, tonsil and liver (see Figures 1 and 2), samples were obtained from healthy animals kept in-house at the Clinic for Swine of the University of Veterinary Medicine Vienna. Pigs were euthanized at the age of six month by a combination of Ketamine (Narketan ${ }^{\circledR}$, Vétoquinol GmbH, Vienna, Austria)/Azaperone (Stresnil ${ }^{\circledR}$, Janssen Pharmaceutica, Beerse, Belgien) anesthesia and T61 ${ }^{\circledR}$ (Intervet GmbH, Vienna, Austria).

For studying intracellular IFN- $\gamma$ production after virus restimulation in vitro, peripheral blood mononuclear cells (PBMCs) were used from animals out of two vaccination/ infection experiments. For porcine reproductive and respiratory syndrome virus (PRRSV) restimulation, four-week old piglets were vaccinated intramuscularly with a PRRSV modified live vaccine (Ingelvac ${ }^{\circledR}$ PRRS MLV, Boehringer Ingelheim Vetmedica $\mathrm{GmbH}$, Germany) and challenged intranasally and intramuscularly with a PRRSV field isolate (EU strain, total dose $2.2 \times 10^{5}$ TCID $_{50}$, ) 35 days later. PBMCs were isolated on day 21 post challenge.

Moreover, for in vitro restimulation with swine influenza A virus (FLUAVsw), five-week old piglets were intratracheally infected with Influenza A virus/swine/ Kitzen/IDT6142/2007 (H1N2, $10^{8.25}$ TCID $_{50}$ per animal, provided by Dr Ralf Dürrwald, IDT Biologika $\mathrm{GmbH}$, Dessau, Germany). Four weeks later, the piglets were infected for a second time with the same FLUAVsw strain and dose. PBMCs were isolated 35 days after the second infection.

Vaccination/infection experiments with piglets were approved by the institutional ethics committee, the Advisory Committee for Animal Experiments ( $\$ 12$ of Law for Animal Experiments, Tierversuchsgesetz - TVG) and the Federal Ministry for Science and Research (reference numbers BMWF-68.205/0232-II/106/2009 for PRRSV vaccination experiment and BMWF-68.205/0180-II/3b/ 2011 for FLUAVsw infection experiment).

Heparinized blood was used for isolation of PBMCs by gradient centrifugation with lymphocyte separation medium (PAA Laboratories, Pasching, Austria) as described elsewhere [1]. Cells from spleen, various lymph nodes and tonsil were obtained as reported previously [11]. Isolation of intrahepatic lymphocytes was performed according to a protocol by Crispe [12]. Cells were re-suspended in appropriate buffers (see below) prior to FCM staining. PBMCs used for intracellular cytokine staining and FACS-sorting experiments were cryopreserved at $-150^{\circ} \mathrm{C}$ as described by Leitner et al. [13].

\section{FCM analyses and antibodies}

For phenotypical analysis of CD27-defined T helper cells within PBMCs, spleen, lymph nodes, tonsil and liver, freshly isolated cells were re-suspended in PBS (without $\mathrm{Ca}^{2+}$ / $\mathrm{Mg}^{2+}, \mathrm{PAA}$ ) and $10 \%(\mathrm{v} / \mathrm{v})$ porcine plasma (in-house preparation) and adjusted to $6 \times 10^{5}$ cells per sample. Samples used to analyse CCR7 expression, were resuspended in PBS (without $\mathrm{Ca}^{2+} / \mathrm{Mg}^{2+}$ ) containing $10 \%(\mathrm{v} / \mathrm{v})$ porcine plasma and $10 \%(\mathrm{v} / \mathrm{v})$ rat serum (PAA). The following primary antibodies were used: CD3-eFluor450 (mIgG1, clone PPT3; custom conjugated to eFluor450 by eBioscience, San Diego, CA, USA), CD4 (mIgG2b, clone 74-12-4), CD8 $\alpha$-PE (mIgG2a, clone 76-2-11; BD Biosciences, San Jose, CA, USA), CD27-Alexa647 (mIgG1, clone b30c7), CD45RC-PerCP-Cy5.5 (mIgG1, clone 3a56), SLA-DR-Qdot605 (mIgG2a, clone MSA3, custom conjugated to Qdot605 by Life Technologies, Carlsbad, 


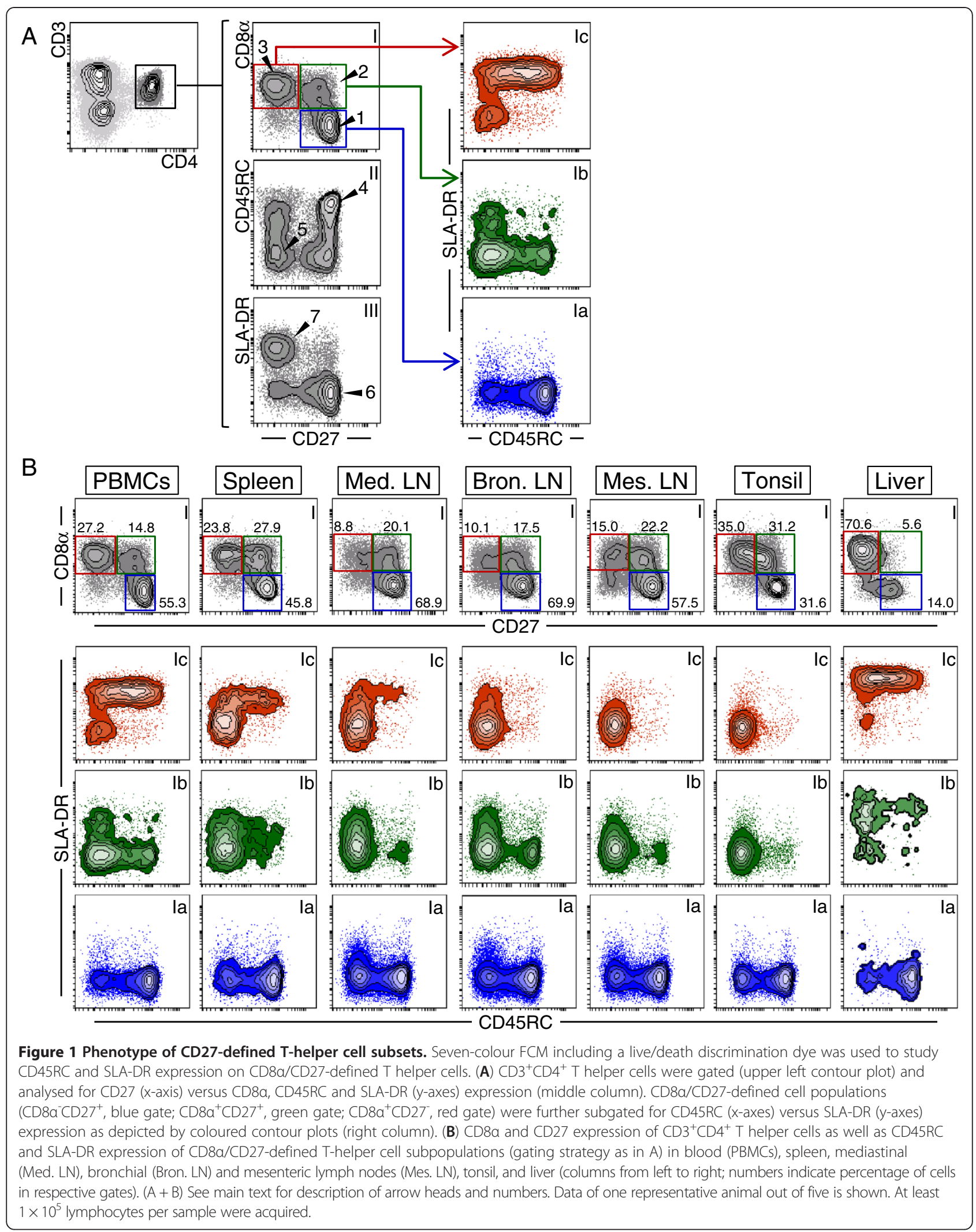


CA, USA) and rat anti-human CD197-PE-Cy7 (CCR7) (rat IgG2a, clone 3D12; BD Biosciences). All noncommercial antibodies were produced in-house [14] and - where indicated - purified and covalently conjugated to fluorochromes by the use of either Alexa Fluor647 Monoclonal Antibody Labeling Kit (Life Technologies) or Lightning Link ${ }^{\mathrm{TM}}$ PerCP/Cy5.5 conjugation kit (Innova Biosciences, Cambridge, UK) according to manufacturer's instructions. In a second incubation step, samples were incubated with goat anti-mouse IgG2bAlexa488 secondary antibody and LIVE/DEAD ${ }^{\circledR}$ Fixable Near-IR dead cell stain (both Life Technologies) as described earlier [11]. For all FCM analyses unspecific binding was evaluated by appropriate isotype-matched control antibodies and compensation settings were calculated based on single-color stained cell samples.

FCM measurements were carried out using a FACSCanto $^{\text {TM }}$ II flow cytometer equipped with FACSDiva software (Version 6.1.3., BD Biosciences).

\section{Intracellular IFN- $\gamma$ staining}

For phorbol 12-myristate 13-acetate (PMA)/Ionomycin stimulation, defrosted PBMCs $\left(2 \times 10^{5}\right.$ per well $)$ were cultured in cell culture medium (RPMI 1640 with stable glutamine supplemented with 10\% [v/v] FCS, $100 \mathrm{IU} / \mathrm{mL}$ penicillin and $0.1 \mathrm{mg} / \mathrm{mL}$ streptomycin (all PAA)) either unstimulated or stimulated with $5 \mathrm{ng} / \mathrm{mL}$ PMA and $500 \mathrm{ng} / \mathrm{mL}$ Ionomycin (both Sigma-Aldrich, St. Louis, $\mathrm{MO}, \mathrm{USA}$ ) in the presence of $1 \mu \mathrm{g} / \mathrm{mL}$ Brefeldin A (BD GolgiPlug ${ }^{\mathrm{TM}}$, BD Biosciences) for $4 \mathrm{~h}$ at $37^{\circ} \mathrm{C}$.

For virus-specific IFN- $\gamma$ analyses, PBMCs $\left(2 \times 10^{5}\right.$ per well) from primed animals were in vitro restimulated with either PRRSV or FLUAVsw in cell culture medium with the respective virus by a multiplicity of infection set to 1 (MOI 1). For PRRSV restimulation, the virus strain present in the vaccine was used. For FLUAVsw restimulation, homologous virus as used for the infections was applied. For both viruses, mock-infected microcultures served as negative controls. Cells were incubated for $24 \mathrm{~h}$ at $37^{\circ} \mathrm{C}$. During the last four hours $1 \mu \mathrm{g} / \mathrm{mL}$ Brefeldin A was added to microcultures.

PBMCs were harvested, washed, resuspended in PBS (without $\mathrm{Ca}^{2+} / \mathrm{Mg}^{2+}$ ) containing $3 \%(\mathrm{v} / \mathrm{v})$ FCS and finally adjusted to $\sim 2.5 \times 10^{6}$ per sample. In a first incubation step, anti-CD4, anti-CD8 $\alpha$ (mIgG2a, clone 11/295/33), and anti-CD27 (clone b30c7) mAbs were added (see above for further details on antibodies). Thereafter, binding of primary antibodies was detected by isotype-matched secondary antibodies: goat anti-mouse IgG1-Alexa488, goat anti-mouse IgG2a-Alexa647 (both Life Technologies) and goat anti-mouse IgG2b-Biotin (Southern Biotech, Birmingham, AL, USA). Free binding sites of secondary 
antibodies were blocked with whole mouse IgG molecules (2 $\mu$ g per sample; Jackson ImmunoResearch, West Grove, PA, USA) before cells were incubated with anti-CD45RCPerCP-Cy5.5 mAb (see above), LIVE/DEAD ${ }^{\circledR}$ Fixable Aqua dead cell stain (Life Technologies) and one of the following streptavidin conjugates: Streptavidin-Qdot605 (Life Technologies, for PMA/Ionomycin stimulation), Streptavidin-Alexa405 (Life Technologies, for PRRSV restimulation) or Streptavidin-eFluor450 (eBiosciences, for FLUAVsw restimulation). Subsequently, cells were fixed and permeabilized as described previously [15] and stained with anti-IFN- $\gamma$-PE mAb (mIgG1, clone P2G10; BD Biosciences).

Fluorescence-activated cell sorting of T-helper cell subsets For sorting of $\mathrm{CD} 4^{+} \mathrm{CD} 8 \alpha^{-} \mathrm{CD} 27^{+}, \mathrm{CD} 4^{+} \mathrm{CD} 8 \alpha^{+} \mathrm{CD} 27^{+}$ and $\mathrm{CD} 4^{+} \mathrm{CD} 8 \alpha^{+} \mathrm{CD} 27^{-} \mathrm{T}$ helper cells as well as $\mathrm{CD} 4^{-}$ $\mathrm{CD}_{172 \mathrm{a}^{+}}$antigen presenting cells (APCs), PBMCs were incubated with primary antibodies against $\mathrm{CD} 8 \alpha$ (clone 11/295/33), CD27 and CD172a (mIgG2b, clone 74-22-15A) [14]. In a second step, binding of primary antibodies was detected with the following isotype-matched secondary antibodies: goat anti-mouse IgG2a-Alexa647 (Life Technologies), goat anti-mouse IgG1-PE and goat anti-mouse IgG2b-Biotin (both Southern Biotech). After blocking free binding sites of secondary antibodies with mouse IgG molecules (Jackson ImmunoResearch), cells were incubated with anti-CD4-FITC mAb (mIgG2b, clone 74-12-4; BD Biosciences) and Streptavidin-Qdot800 conjugate (Life Technologies) in a fourth incubation step. All washing steps were performed with PBS (without $\mathrm{Ca}^{2+} / \mathrm{Mg}^{2+}$ ) containing 5\% (v/v) FCS and 2 mM EDTA (Carl Roth, Karlsruhe, Germany). Finally, cells were subjected to sorting using a FACSAria cell sorter (BD Biosciences) equipped with FACSDiva software (Version 6.1.3., BD Biosciences). The purity of sorted cell populations was 97.6 - 99.9\% (mean purity: $99.2 \%$ ).

\section{Proliferation assays}

For tritium-incorporation assays total PBMCs, $\mathrm{CD} 4^{+} \mathrm{CD} 8 \alpha^{-}$ $\mathrm{CD} 27^{+}-, \quad \mathrm{CD} 4^{+} \mathrm{CD} 8 \alpha^{+} \mathrm{CD} 27^{+}$- and $\mathrm{CD} 4^{+} \mathrm{CD} 8 \alpha^{+} \mathrm{CD} 27^{-}-$ sorted cells $\left(1.8 \times 10^{5}\right.$ per well $)$ were plated in triplicates and either cultured in cell culture medium alone or stimulated with $5 \mu \mathrm{g} / \mathrm{mL}$ Concanavalin A (ConA) (Amersham Biosciences, Uppsala, Sweden) and $10 \mathrm{IU} / \mathrm{mL}$ recombinant human (rh) IL-2 (Roche, Mannheim, Germany). In addition, CD172 $\mathrm{a}^{+}$APCs were added to sorted microcultures in a 1:10 ratio. Cells were cultured for 3 days and subsequently pulsed with $1 \mu \mathrm{Ci}$ of ${ }^{3} \mathrm{H}$-thymidine (MP Biomedicals, Eschwege, Germany) per well for additional $18 \mathrm{~h}$. Thereafter, cells were harvested with a Filtermate Harvester (Perkin Elmer, Wellesley, MA, USA). ${ }^{3} \mathrm{H}$-thymidine uptake was quantified in counts per minutes (cpm) by a Top Count 4.00 Scintillation Counter (Perkin Elmer).
For proliferation analyses by $\mathrm{FCM}, \mathrm{CD} 4^{+} \mathrm{CD} 8 \alpha^{-} \mathrm{CD} 27^{+}$, $\mathrm{CD} 4{ }^{+} \mathrm{CD} 8 \alpha^{+} \mathrm{CD} 27^{+}$- and $\mathrm{CD} 44^{+} \mathrm{CD} 8 \alpha^{+} \mathrm{CD} 27^{-}$-sorted cells $\left(5 \times 10^{6}\right.$ cells per sorted fraction) were washed and labelled with CellTrace ${ }^{\mathrm{TM}}$ Violet Cell Proliferation Kit (Life Technologies) as described elsewhere [11]. Afterwards, labelled T-helper cell subsets $\left(1.8 \times 10^{5}\right.$ cells per well $)$ were cultivated in presence of $\mathrm{CD} 172 \mathrm{a}^{+}$APCs $\left(2 \times 10^{4}\right.$ cells per well) either in cell culture medium alone or stimulated with $5 \mu \mathrm{g} / \mathrm{mL}$ ConA and $10 \mathrm{IU} / \mathrm{mL}$ rhIL-2 for 4 days. Thereafter, cells were washed and resuspended in PBS (without $\mathrm{Ca}^{2+} / \mathrm{Mg}^{2+}$ ) containing 3\% (v/v) FCS. Cell samples were re-stained for $\mathrm{CD} 4, \mathrm{CD} 8 \alpha$ and $\mathrm{CD} 27$ expression by use of anti-CD4 (clone 74-12-4), CD8 $\alpha$ and CD27 mAbs. In a second incubation step, the following secondary antibodies were added: goat anti-mouse IgG2b-Alexa488, goat anti-mouse IgG2a-Alexa647 (both Life Technologies) and goat anti-mouse IgG1-PE (Southern Biotech). After two final washes, cells were analysed by FCM. Data was processed by FlowJo software (Version 7.6.3., Tree Star, Ashland, OR, USA).

\section{Cytokine ELISAs}

Supernatants of PBMCs, CD $4^{+} \mathrm{CD} 8 \alpha^{-} \mathrm{CD} 27^{+}-, \mathrm{CD} 4^{+}$ $\mathrm{CD} 8 \alpha^{+} \mathrm{CD} 27^{+}$- and $\mathrm{CD} 4^{+} \mathrm{CD} 8 \alpha^{+} \mathrm{CD} 27^{-}$-sorted cells stimulated for proliferation analysis (see above) were collected after four days of cultivation. IFN- $\gamma$, TNF- $\alpha$, and IL-2 levels were tested with commercially available porcine IFN- $\gamma$ ELISA kit (Mabtech, Nacka Strand, Sweden), porcine TNF-alpha DuoSet (R\&D Systems, Minneapolis, MN, USA), and Swine IL-2 CytoSet kit (Biosource Europe SA, Nivelles, Belgium), respectively. Optical density was measured at $450 / 620 \mathrm{~nm}$ with a Sunrise ELISA reader (Tecan, Crailsheim, Germany).

\section{RNA isolation and quantitative RT-PCR (qPCR)}

Total RNA was extracted from $\mathrm{CD} 44^{+} \mathrm{CD} 8 \alpha^{-} \mathrm{CD} 27^{+}$-, $\mathrm{CD} 4{ }^{+} \mathrm{CD} 8 \alpha^{+} \mathrm{CD} 27^{+}$- and $\mathrm{CD} 4{ }^{+} \mathrm{CD} 8 \alpha^{+} \mathrm{CD} 27^{-}$-sorted cells using TRI REAGENT ${ }^{\mathrm{TM}}$ (Sigma-Aldrich, Vienna, Austria) according to manufacturer's protocol. RNA quality control and cDNA synthesis were performed as described elsewhere [16]. Aliquots from each cDNA sample investigated in this study were pooled to generate an internal standard (IS), which was used as reference for the quantification.

Primer pairs used to analyse the expression of CD62L and CX3CR1 were newly designed and sequence details are listed in Table 1. Primers (Eurofins MWG Operon, Ebersberg, Germany) were forced to span over exon junctions in order to increase specificity. Conditions for the amplification and validation of the qPCR assays are summarized in Additional file 1 . Specificity of the generated PCR products using a cDNA pool was verified by automated sequencing using the pGEM-T Easy vector system (Promega, Madison, WI, USA) and M13 standard sequencing primer (Eurofins MWG Operon). 
Table 1 Primer pairs used for quantification of gene expression by qPCR

\begin{tabular}{llllcc}
\hline Target & Accession number & $\begin{array}{l}\text { Primer sequence Forward (F), } \\
\text { Reverse (R) }\end{array}$ & Position on + strand & Product length (bp) & Source \\
\hline CD62L & NM_001112678.1 & F: AGCAAAGACTCCGGGAAGTG & 404 & 247 & designed by primer3 [17] \\
& & R: AGAACTTGCCCAAAGGGTGA & 651 & -67 & designed by primer \\
CX3CR1 & XM_003358374.1 & F: CGCAGGACAGGGTGGCGGAT & 150 & 217 & BLAST [18]
\end{tabular}

Sequences of primers $\left(5^{\prime}-3^{\prime}\right)$, primer positions on $(+)$ strand relative to the ATG start codon and product length in base pairs (bp) are indicated.

The target genes were analysed using $\mathrm{SYBR}^{\circledR}$ green I $(\times 0.5$, Sigma $)$ as reporter dye. The $\mathrm{qPCR}$ reactions contained iTaq $^{\mathrm{TM}}$ polymerase $^{\mathrm{TM}}(0.3 \mathrm{U} /$ reaction; Bio-Rad $)$, gene specific primers $(250 \mathrm{nmol} / \mathrm{L}$ each), a final concentration of $200 \mu \mathrm{mol} / \mathrm{L} \mathrm{dNTP} \mathrm{each} \mathrm{and} 3 \mathrm{mmol} / \mathrm{L} \mathrm{MgCl}_{2}$ in the provided reaction buffer $(1 \times)$. Real-time PCR was performed on a CFX96 ${ }^{\mathrm{TM}}$ (Bio-Rad, Hercules, CA, USA). The multiplex qPCR assay for the reference genes ( $\beta$-Actin, Cyclophilin A and GAPDH) was conducted as described previously [19]. Each plate contained corresponding randomly assigned RT-minus controls (30\% of all samples investigated), the no-template controls (NTCs) as well as the IS.

Data were analysed using the CFX manager software (Bio-Rad) in the linear regression mode. For the quantification, we applied the method as described elsewhere [19]. The obtained $\Delta \Delta \mathrm{Cq}$ values of the replicates were averaged and expressed as $2^{\wedge}-\Delta \Delta C q$ values representing the fold changes relative to IS.

\section{Statistical analysis}

Statistical analyses were performed using SPSS $^{\circledR}$ (IBM, Armonk, NY, USA) Version 20. Means of sorted T-helper cell subsets were proved for normal distribution by the Kolmogorov-Smirnov test. Data sets were subjected to multiple comparisons using one-way analysis of variance with the Bonferroni correction. Two different levels of significance were defined: $p<0.05$ (indicated by *) and $p<0.01$ (indicated by ${ }^{* * *}$ ).

\section{Results}

Phenotypic analyses of porcine $T$ helper cells for CD27 expression in combination with CD8a, CD45RC and SLA-DR FCM analysis of PBMCs was performed to examine CD27 expression on $\mathrm{CD}^{+} \mathrm{CD}^{+}{ }^{+} \mathrm{T}$ helper cells in combination with three established activation and differentiation markers for swine: CD8 $\alpha, C D 45 R C$ and SLA-DR [3] (Figure 1a, contour plot series "I - III"). Combined analysis of $\mathrm{CD} 27$ and $\mathrm{CD} 8 \alpha$ revealed three major subsets: $\mathrm{CD} 8 \alpha^{-} \mathrm{CD} 27^{+}$(arrow head "1"), $\mathrm{CD} 8 \alpha^{+} \mathrm{CD} 27^{+}$ (arrow head "2") and $\mathrm{CD} 8 \alpha^{+} \mathrm{CD} 27^{-} \mathrm{T}$ helper cells (arrow head "3"). Moreover, $\mathrm{CD}^{+} \mathrm{CD} 4^{+}$total $\mathrm{T}$ helper cells showed a heterogeneous expression for CD45RC within $\mathrm{CD} 27^{+}$and $\mathrm{CD} 27^{-} \mathrm{T}$ helper cells, but in tendency the majority of $\mathrm{CD}^{+} 7^{+}$cells co-expressed CD45RC (arrow head "4"), whereas cells lacking CD45RC slightly dominated within the CD27 population (arrow head " 5 "). In contrast, within this population of $\mathrm{CD}^{+}$ $\mathrm{CD}^{+}{ }^{+}$total $\mathrm{T}$ helper cells almost all $\mathrm{CD} 27^{+}$cells were SLA-DR" (arrow head "6"), whereas SLA-DR was clearly expressed on the majority of $\mathrm{CD}^{-} \mathrm{T}$ helper cells (arrow head "7").

Analyses of $\mathrm{CD} 8 \alpha$ and $\mathrm{CD} 27$ co-expression on $\mathrm{CD}^{+}$ $\mathrm{CD}^{+} \mathrm{T}$ helper cells were expanded to lymphocytes isolated from secondary lymphatic organs and liver (Figure 1b, contour plot series I). CD8 $\alpha^{-} \mathrm{CD} 27^{+} \mathrm{T}$ helper cells abounded in lymph nodes (> 57.5\%), PBMCs (55.3\%) and spleen (45.8\%). In contrast, in liver $\mathrm{CD} 8 \alpha^{+} \mathrm{CD} 27^{-} \mathrm{T}$ helper cells dominated (70.6\%), and the frequency of this population descended from tonsil (35.0\%) to PBMCs (27.2\%). Of note, in liver, besides few $\mathrm{CD} 8 \alpha^{-} \mathrm{CD} 27^{+}$and mostly $\mathrm{CD} 8 \alpha^{+} \mathrm{CD} 27^{-} \mathrm{T}$ helper cells, a small subset was found that neither expressed CD8 $\alpha$ nor CD27 molecules. On the contrary, $\mathrm{CD} 8 \alpha^{+} \mathrm{CD} 27^{+} \mathrm{T}$ helper cells were almost entirely absent $(5.6 \%)$ in liver.

Based on the prevalence of three CD8 $\alpha / C D 27$-defined T-helper cell subsets, further phenotypic analyses of CD45RC and SLA-DR expression were attributed to these three subsets (Figure 1a and b; contour plots "I"): $\mathrm{CD} 8 \alpha^{-} \mathrm{CD} 27^{+}$(blue gate, series "Ia"), $\mathrm{CD} 8 \alpha^{+} \mathrm{CD} 27^{+}$ (green gate, series "Ib") and $\mathrm{CD} 8 \alpha^{+} \mathrm{CD} 27^{-}$(red gate, series "Ic"). In PBMCs, secondary lymphatic organs and liver, $\mathrm{CD} 8 \alpha^{-} \mathrm{CD} 27^{+}$cells contained a major subset of CD45RC ${ }^{+}$cells and a minor subset of $\mathrm{CD}^{-} 5 \mathrm{RC}^{-}$cells which were both SLA-DR (Figure $1 \mathrm{~b}$, contour plot series "Ia"). In contrast, the majority of $\mathrm{CD} 8 \alpha^{+} \mathrm{CD} 27^{+} \mathrm{T}$ helper cells were CD45RC' (contour plot series "Ib"). Moreover, except for the tonsil, SLA-DR expression was identified on a subset of $\mathrm{CD} 8 \alpha^{+} \mathrm{CD} 27^{+} \mathrm{CD} 45 \mathrm{RC}^{-}$cells. For $\mathrm{CD} 8 \alpha^{+} \mathrm{CD} 27^{-} \mathrm{T}$ helper cells (contour plot series "IC") within PBMCs and liver, the majority of cells displayed SLA-DR ${ }^{+}$expression, while CD45RC was heterogeneously expressed. SLA-DR expression was also found on few $\mathrm{CD} 8 \alpha^{+} \mathrm{CD} 27^{-} \mathrm{T}$ helper cells obtained from spleen, mediastinal and bronchial lymph nodes and the vast majority of these cells lacked CD45RC expression. In mesenteric lymph node and tonsil nearly all $\mathrm{CD} 8 \mathrm{\alpha}^{+} \mathrm{CD} 27^{-} \mathrm{T}$ helper cells had a CD45RC'SLA-DR phenotype. 
In addition to the hierarchical phenotypic analysis performed in Figure 1, a boolean gating was performed in order to address the complex distribution of phenotypes of $\mathrm{T}$ helper cells within various organs (Figure 2). Sixteen distinct $\mathrm{CD}^{+} \mathrm{CD}^{+}{ }^{+} \mathrm{T}$-helper cell subsets were defined for CD8 $\alpha$, CD27, CD45RC and SLA-DR expression as illustrated by the legend in Figure 2. Based on the expression of CD27 and CD8 $\alpha$, phenotypes of these subsets were clustered into four groups: i) T helper cells with a presumed naïve phenotype, i.e. $\mathrm{CD} 8 \alpha^{-} \mathrm{CD} 27^{+}$ (light blue to dark blue), ii) T helper cells that co-expressed CD27 and CD8 $\alpha$ (light green to dark green), iii) $\mathrm{T}$ helper cells that were $\mathrm{CD} 8 \alpha^{+}$but $\mathrm{CD}^{-} 7^{-}$(yellow to red), and iv) according to results from Figure 1, $\mathrm{T}$ helper cells with the rare phenotype $\mathrm{CD} 8 \alpha^{-} \mathrm{CD} 27^{-}$(white, grey and black). Analyses of five animals revealed large numbers of CD8 $\alpha^{-}$CD $27^{+}$SLA-DR ${ }^{-}$T helper cells which were either

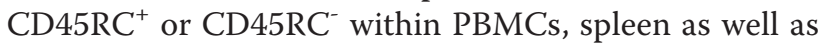
mediastinal, bronchial and mesenteric lymph nodes (faint blue and light blue, respectively). In tonsils $\mathrm{T}$ helper cells predominantly resided with a common CD $8 \alpha^{+}$CD45RC ${ }^{-}$SLA-DR ${ }^{-}$phenotype, but this subset consisted of $\mathrm{CD}_{27}{ }^{+}$and $\mathrm{CD} 27^{-}$cells (light green and ochre yellow, respectively). Also, compared to lymph nodes, in PBMCs and spleen more CD8 $\alpha^{+} \mathrm{CD} 27^{-} \mathrm{SLA}^{-} \mathrm{DR}^{+}$cells, which were either $\mathrm{CD}_{4} 5 \mathrm{RC}^{+}$or $\mathrm{CD} 45 \mathrm{RC}^{-}$, were localized (light red and red, respectively). The proportion of CD27 T-helper cell subsets was highest in liver (ochre yellow, orange and red). Moreover, in liver many CD $8 \alpha^{-} \mathrm{CD} 27^{-}$ cells with currently unknown relevance were discovered (white, light grey, black). Overall, the highest diversity of subsets was observed for T-helper cell subsets in PBMCs, spleen and liver.

\section{IFN- $\gamma$ production of T-helper cell subsets after polyclonal stimulation and virus-specific restimulation in vitro}

To correlate the phenotype of CD27-defined T-helper cell subsets with functional properties, in a first set of experiments PBMCs were stimulated with PMA/ Ionomycin or restimulated with either PRRSV or FLUAVsw. Following stimulation, IFN- $\gamma$ production of $\mathrm{T}$ helper cells was analysed in combination with CD4, CD8 $\alpha$, CD27 and CD45RC expression by FCM (Figure 3). PMA/Ionomycin provoked IFN- $\gamma$ production in $13.60 \%$ of $\mathrm{T}$ helper cells. Of note, only $\mathrm{CD} 8 \alpha^{+} \mathrm{T}$ helper cells produced IFN- $\gamma$. Furthermore, the majority of IFN $-\gamma^{+} \mathrm{T}$ helper cells were $\mathrm{CD}_{45 \mathrm{RC}}^{-}$, whereas both $\mathrm{CD}_{2} 7^{+}$and CD27 ${ }^{-} \mathrm{T}$ helper cells were capable of producing IFN- $\gamma$. Restimulation with viruses induced much higher levels of IFN- $\gamma$ producing $\mathrm{T}$ helper cells ( 20-fold) compared to respective mock stimulated microcultures, thereby demonstrating the specificity of the response. PRRSV induced IFN- $\gamma$ production in $0.20 \%$ and FLUAVsw in $0.62 \%$ of $\mathrm{T}$ helper cells. Similar to PMA/Ionomycin,
PRRSV and FLUAVsw solely stimulated CD $8 \alpha^{+} \mathrm{T}$ helper cells for IFN- $\gamma$ release. Again, both viruses caused IFN- $\gamma$ production of $\mathrm{CD} 27^{+}$and $\mathrm{CD} 27^{-} \mathrm{T}$ helper cells, but in tendency more $\mathrm{CD} 27^{+} \mathrm{IFN}-\gamma^{+}$cells were observed. In regard to CD45RC, for PRRSV most virus-specific IFN- $\gamma^{+}$ T helper cells were CD45RC', but FLUAVsw evoked more $\mathrm{CD}_{45 \mathrm{RC}^{+}}$responding cells. In summary, these results indicate that in vivo primed $\mathrm{T}$ helper cells are $\mathrm{CD} 8 \alpha^{+}$but show heterogeneous phenotypes for CD27 and CD45RC.

\section{Differences in cytokine production and proliferation between CD27-sorted T-helper cell subsets}

In a next series of experiments, functional analyses of FACS-sorted $\mathrm{CD} 4{ }^{+} \mathrm{CD} 8 \alpha^{-} \mathrm{CD} 27^{+}$(now designated as naïve), $\mathrm{CD} 4{ }^{+} \mathrm{CD} 8 \alpha^{+} \mathrm{CD} 27^{+}$(designated as $\mathrm{CD} 27^{+}$) and $\mathrm{CD} 4^{+}$ $\mathrm{CD} \alpha^{+} \mathrm{CD}^{-} 7^{-}$(designated as CD27 ${ }^{-}$T-helper cell subsets were performed. Sorted cell fractions were cultivated with ConA and rhIL-2 for 4 days and proliferation as well as production of the cytokines IFN- $\gamma$, TNF- $\alpha$ and IL- 2 in supernatants was analysed (Figure 4). Results for cytokine production of one representative animal, but also mean values for six individuals are shown in Figure $4 \mathrm{a}$ and b, respectively. $\mathrm{CD}^{-} \mathrm{T}$ helper cells produced the highest amounts of IFN- $\gamma$ and TNF- $\alpha$ after 4 days of cultivation (Figure 4a). CD27 ${ }^{+} \mathrm{T}$ helper cells reached IFN- $\gamma$ and TNF- $\alpha$ levels similar to unsorted PBMCs. In contrast, the highest detectable IL-2 production was observed for naïve $\mathrm{T}$ helper cells. These observations were confirmed by analyses with cells from six individuals (Figure 4b). In addition to cytokine production on day 4 , time kinetics of cytokine production for $\mathrm{T}$ helper cells from one animal were analysed (Additional file 2). Interestingly, considerable IFN- $\gamma$ production of CD27 ${ }^{-} \mathrm{T}$ helper cells was not observed before day 2. In contrast, TNF- $\alpha$ level of CD27 $\mathrm{T}$ helper cells was already high on day 1 . Naïve $T$ helper cells produced no detectable levels of IL-2 on day 1 , but production rapidly increased on day 2.

Proliferation of sorted CD8 $\alpha / C D 27$ T-helper cell subsets was analysed by tritium incorporation as well as dilution of violet proliferation dye in response to polyclonal stimulation (Figure $4 \mathrm{c}$ and d, respectively). Tritium incorporation revealed that naïve and $\mathrm{CD}_{2} 7^{+} \mathrm{T}$ helper cells had similar proliferation capacities, but $\mathrm{CD}^{-} \mathrm{T}$ helper cells showed the lowest tritium incorporation (Figure 4c). These findings were also evidenced by violet proliferation assays. Naïve and $\mathrm{CD}_{2} 7^{+} \mathrm{T}$ helper cells showed overall similar proliferation indices (PI, average number of cell cycles of responding cells) as well as percentages of divided cells after four days of stimulation (Figure 4d). In opposition to these subsets, CD27 ${ }^{-} \mathrm{T}$ helper cells clearly demonstrated lowest proliferation rates plus abortive proliferation patterns in two out of three animals tested (pig \#3 and \#4). The CD27 subset of one animal did not show any proliferation at all (pig \#5). 


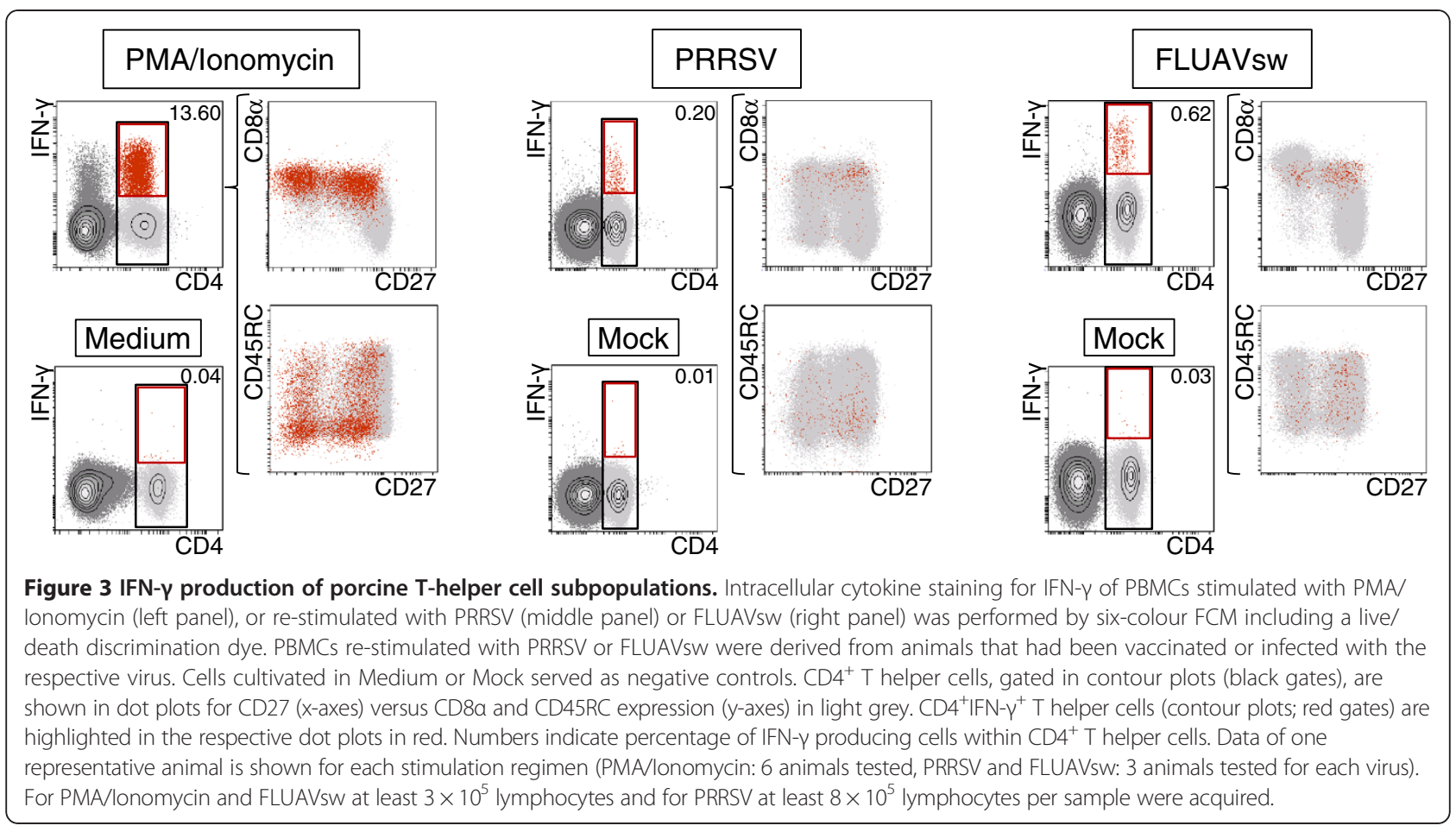

\section{Phenotypical changes in CD8a/CD27 expression on proliferating $\mathrm{T}$-helper cell subsets}

FACS-sorted and violet-labelled T-helper cell subsets were also analysed for potential changes of CD $8 \alpha$ and CD27 expression during in vitro cultivation following polyclonal stimulation (Figure 5 ). On naïve T helper cells CD8 $\alpha$ expression was up-regulated on proliferating cells (Figure 5a, arrow head "1"), whereas CD27 expression was barely affected during cultivation. For $\mathrm{CD} 27^{+}$and CD27- sorted T-helper cell fractions, CD8 $\alpha$ expression remained unaffected. In regard to $\mathrm{CD} 27$, a small proportion of $\mathrm{CD} 27^{+} \mathrm{T}$ helper cells seemed to down-regulate the CD27 molecule on the cell surface (Figure $5 \mathrm{a}$, arrow head "2"), and similarly but reverse, a conversion into a CD27 ${ }^{+}$phenotype was observed for a minor fraction of CD27 $\mathrm{T}$ helper cells (arrow head " 3 "). These data were confirmed by a quantitative analysis of the phenotypes in relation to cell generations generated in vitro (Figure $5 b$ ). Mean values for CD8 $\alpha$ expression on naïve $T$ helper cells from three animals showed a very strong increase of $\mathrm{CD} 8 \alpha^{+}$cells up to numbers similar to $\mathrm{CD} 27^{+}$and $\mathrm{CD} 27^{-}$subsets after five or six division cycles. Although naïve $\mathrm{T}$ helper cells showed a more stable CD27 expression than $\mathrm{CD}^{2} 7^{+} \mathrm{T}$ helper cells, the vast majority of both subsets maintained CD27 expression for 4 days following stimulation, regardless of the number of cell divisions. As described above, a weak increase of CD27 ${ }^{+}$cells was observed within CD27- $\mathrm{T}$ helper cells around generation 3 .

\section{Expression of the chemokine-receptors CCR7 and CX3CR1 and the cell adhesion molecule CD62L on CD27-defined T-helper cell subsets}

Results described in Figure 4 suggest that $\mathrm{CD} 8 \alpha^{+} \mathrm{CD} 27^{+}$ and $\mathrm{CD} 8 \alpha^{+} \mathrm{CD} 27^{-} \mathrm{T}$ helper cells have functional similarities towards central (high proliferation capacity) and effector (rapid production of effector cytokines) memory $\mathrm{T}$ cells, respectively, as described in human and mouse [20]. To address this hypothesis, we performed phenotypical analyses for the CD8 $\alpha / C D 27$ defined T-helper cell subsets with markers used to identify these memory cell subsets in human, namely, CCR7 and CD62L [8]. Since cross-reactivity of an anti-human CCR7 antibody was recently confirmed for cattle [21] and a specific antibody has not been established for swine so far, we compared the porcine CCR7 amino acid sequence with the sequences from human and cattle. Marked similarities were found, including the binding site of the monoclonal antibody on the N-terminal end of the CCR7 molecule (Additional file 3). Consequently, the human CCR7 antibody was tested and reactivity with porcine lymphocytes could be verified (Figure 6a). $\mathrm{CD}^{+} \mathrm{T}$ helper cells isolated from blood, spleen and mediastinal lymph nodes were gated, analysed for $\mathrm{CD} 8 \alpha$ and CD27 expression and CD8 $\alpha / C D 27-$ defined subpopulations investigated for CCR7 expression. All naïve CD $8 \alpha^{-} \mathrm{CD} 27^{+} \mathrm{T}$ helper cells expressed CCR7 (arrow heads "1"). Moreover, the vast majority of $\mathrm{CD}_{2} 7^{+} \mathrm{T}$ helper cells were $\mathrm{CCR}^{+}$in 

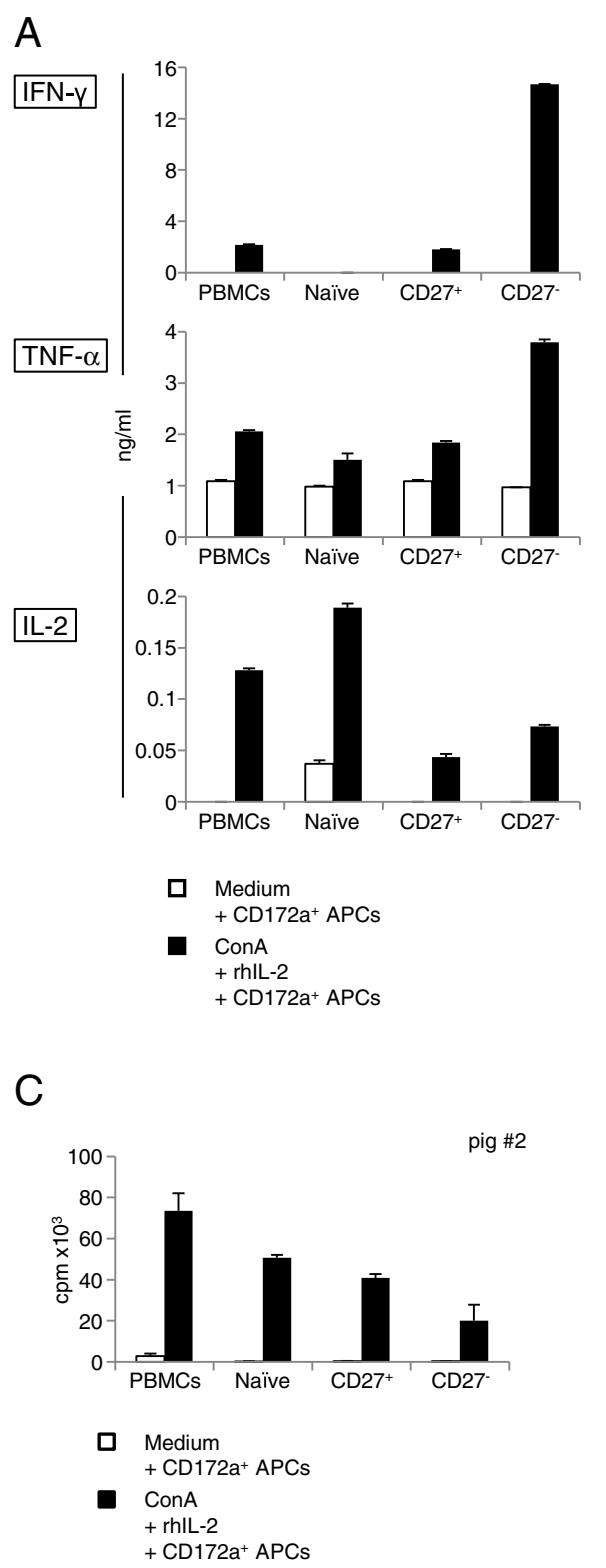

B
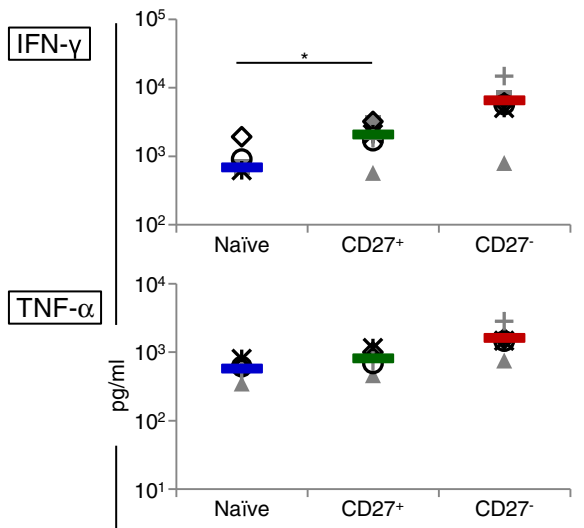

IL-2

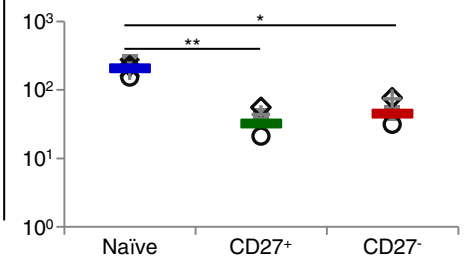

$\begin{array}{ll}\text { pig\#1 } & \bigcirc \text { pig \#4 } \\ \diamond \text { pig \#2 } & \text { X pig \#5 } \\ \triangle \text { pig \#3 } & + \text { pig \#6 }\end{array}$
$\mathrm{D}$

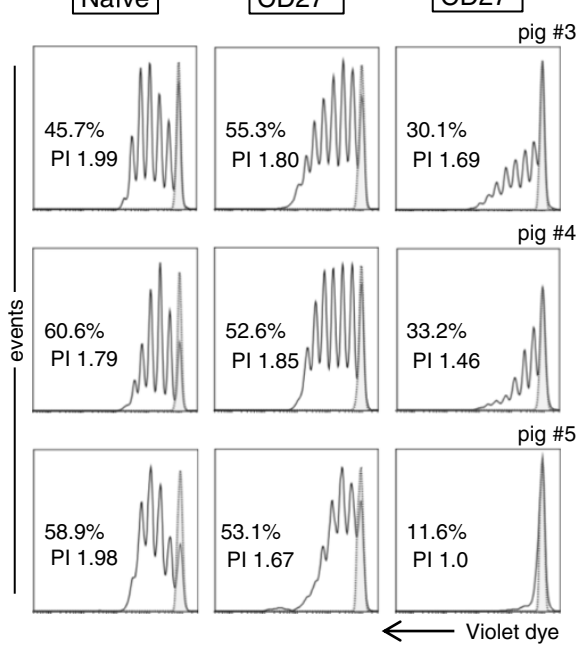

Figure 4 Cytokine production and proliferation of CD27-sorted T-helper cell subsets. FACS-sorted $C D 4^{+} \mathrm{CD} 8 \mathrm{C}^{-} \mathrm{CD} 27^{+}$(naive), $\mathrm{CD} 4^{+} \mathrm{CD} 8 \mathrm{a}^{+} \mathrm{CD} 27^{+}$ $\left(C D 27^{+}\right)$and $\mathrm{CD}^{+} \mathrm{CD} 8 \mathrm{a}^{+} \mathrm{CD} 27(\mathrm{CD} 27)$ cells were cultured in the presence of $10 \% \mathrm{CD} 172 \mathrm{a}^{+} \mathrm{APCs}$. Microcultures were cultivated in Medium alone or

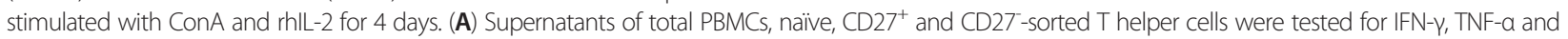
IL-2 levels by ELISAs. The bar graphs represent mean values + standard deviations of duplicate wells in $\mathrm{ng} / \mathrm{mL}$. Representative data of supernatants from one animal out of six is shown. (B) Cytokine production of naïve-, CD27 ${ }^{+}$- and CD27-sorted T helper cells. Cytokine production in supernatants of cell cultures from six pigs is displayed in $\mathrm{pg} / \mathrm{mL}$ on a logarithmic scale. The coloured bars indicate the mean values of the six individuals for each T-helper cell subset. Significant differences are denoted $\left({ }^{*} p<0.05,{ }^{* *} p<0.01\right)$. (C) Total PBMCs, naïve-, CD27 ${ }^{+}$- and CD27-sorted Thelper cells were analysed for tritium incorporation at day 3 to 4 of cultivation. The bar graph shows counts per minute (cpm) on the $y$-axis, representing the mean + standard deviation of triplicate cultures. Data is representative for one experiment with cells from one animal out of two. (D) Naive- (left column), CD27 ${ }^{+}$- (middle column) and CD27-sorted (right column) T helper cells were labelled with violet proliferation dye prior to cultivation and analysed for proliferation by FCM after four days. Percentage divided and proliferation index (PI) of proliferative cells were determined using FlowJo software and are depicted in the graphs. The dotted lines indicate cells that have not divided as calculated by FlowJo software. Per sample at least $2 \times 10^{4}$ cells were recorded. Data of three animals (top to bottom) are shown. 


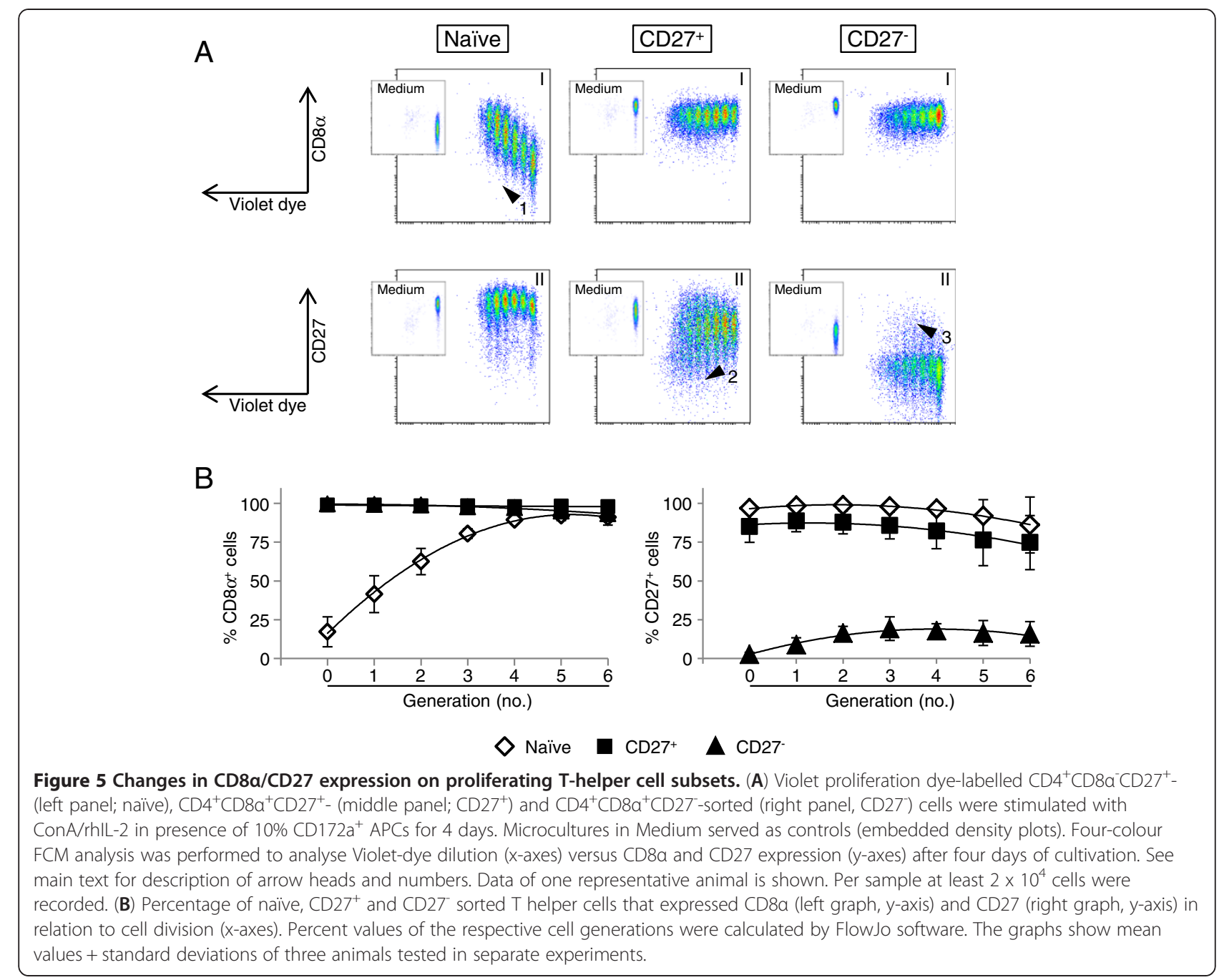

PBMCs (arrow head "2"), whereas CCR7' cells became evident in spleen and mediastinal lymph node (arrow heads "3"). For CD27- $\mathrm{T}$ helper cells, in blood a mixed population of CCR7 $7^{+}$and CCR7 $7^{-}$cells was identified (arrow head "4"), but in spleen and mediastinal lymph node CCR7 cells substantially prevailed (arrow heads " 5 ").

For the adhesion molecule CD62L, quantitative RT-PCR was performed with FACS-sorted $\mathrm{CD} 4^{+} \mathrm{CD} 8 \alpha^{-} \mathrm{CD} 27^{+}$ (naïve), $\mathrm{CD} 4^{+} \mathrm{CD} 8 \alpha^{+} \mathrm{CD} 27^{+}\left(\mathrm{CD} 27^{+}\right)$and $\mathrm{CD} 4^{+} \mathrm{CD} 8 \alpha^{+}$ CD27 (CD27 ${ }^{-}$) T-helper cell subsets isolated from blood (Figure 6b), since antibodies for this molecule in swine are currently not available. Highest mRNA levels of CD62L were found in naïve T helper cells. CD62L transcript levels were already reduced in $\mathrm{CD} 27^{+} \mathrm{T}$ helper cells and lowest levels were found in $\mathrm{CD}^{-} \mathrm{T}$ helper cells. In addition to CD62L, expression of the fractalkine receptor CX3CR1 was analysed at mRNA level (Figure 6b), since CD27 cytotoxic $\mathrm{T}$ lymphocytes and $\mathrm{T}$ helper cells from human
PBMCs were shown to express this molecule [22]. Indeed, in porcine $\mathrm{CD}^{-} \mathrm{T}$ helper cells we also found high CX3CR1 mRNA expression, whereas transcripts for this chemokine-receptor were reduced in $\mathrm{CD} 27^{+} \mathrm{T}$ helper cells and lowest levels were found in naïve $\mathrm{T}$ helper cells.

\section{Discussion}

During the last decades $\mathrm{CD} 8 \alpha$, and to a lesser extent, CD29, CD45RA, CD45RC, 2E3 and SLA-DR were analysed as differentiation antigens for the characterization of porcine memory $\mathrm{T}$ helper cells [3-6,23-25]. In a model suggested by our group [3], naïve $\mathrm{T}$ helper cells were defined by their $\mathrm{CD} 8 \alpha^{-} \mathrm{CD} 45 \mathrm{RC}^{+} \mathrm{SLA}-\mathrm{DR}^{-}$expression, whereas memory $\mathrm{T}$ helper cells were ascribed to a $\mathrm{CD} 8 \alpha^{+} \mathrm{CD} 45 \mathrm{RC}^{-}$ SLA-DR ${ }^{+}$phenotype. In a more recent study, we analysed CD27 expression on porcine $\mathrm{T}$ and NK cells and identified CD27 cells within activated CD $8 \alpha^{+} \mathrm{T}$ helper cells. Therefore, we postulated CD27 as a marker for further 


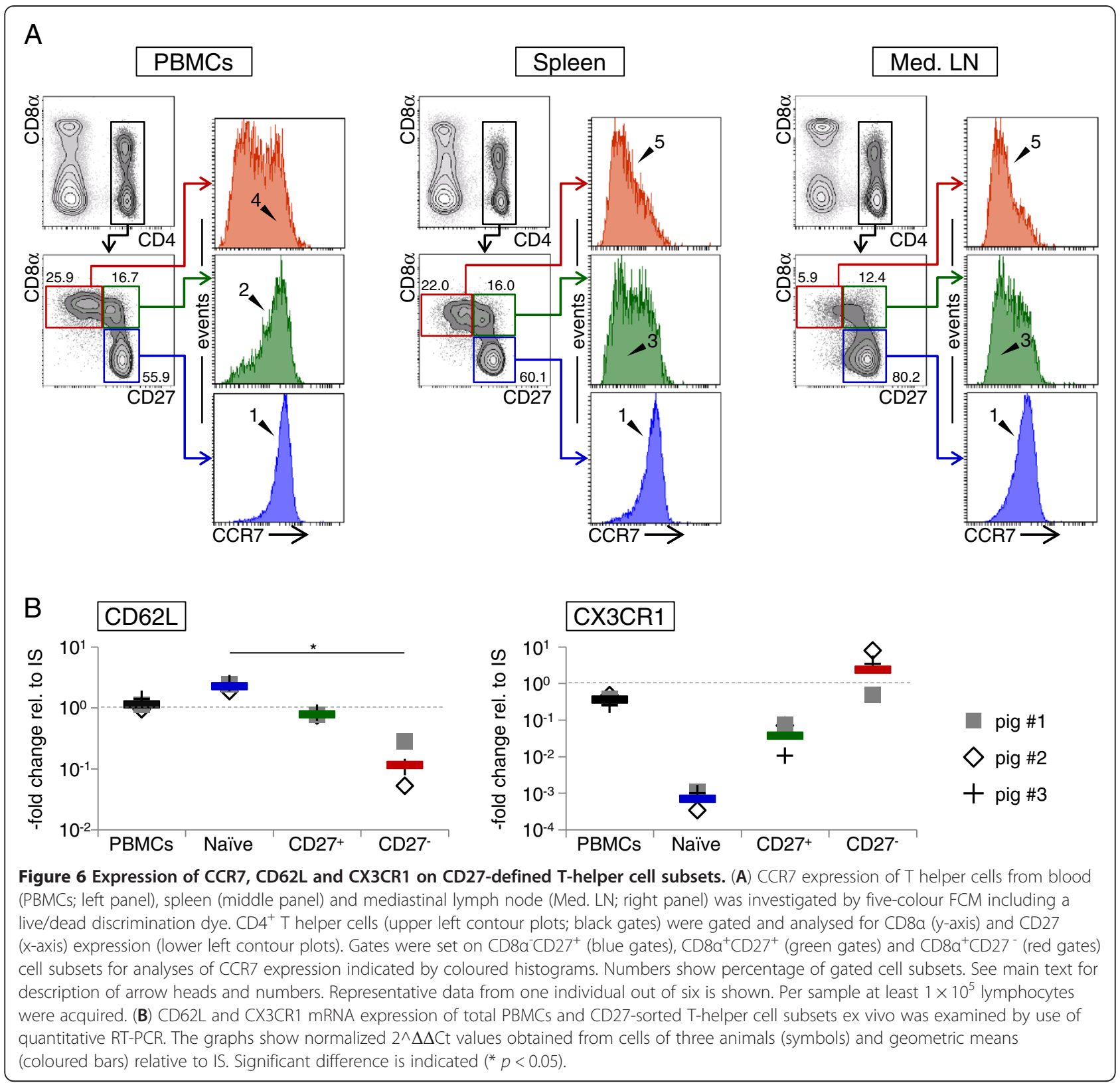

discrimination of functional T-helper cell subsets in swine [11] since lack of $\mathrm{CD} 27$ on human $\mathrm{CD} 4^{+}$memory $\mathrm{T}$ cells denotes a late stage of differentiation [26,27].

In the present study, we analysed CD27 expression in combination with CD8 $\alpha$, CD45RC and SLA-DR to enable a correlation between older and more recent phenotypic data on porcine $\mathrm{T}$ helper cells. Naïve CD8 $\alpha^{-} \mathrm{T}$ helper cells were mostly $\mathrm{CD}_{2} 7^{+}$and SLA-DR ${ }^{-}$but contained a major CD45RC ${ }^{+}$and a minor CD45RC $\mathrm{C}^{-}$subset, most notably in lymph nodes and tonsil. However, in PBMCs and spleen the majority of these cells were CD45RC $\mathrm{C}^{+}$(Figure 1b, contour plot series "Ia" and Figure 2, faint blue versus light blue populations). This indicates that the lack of CD45RC expression alone is not a suitable phenotype for the identification of activated or memory porcine $\mathrm{T}$ helper cells. Moreover, since CD45RC expression was nearly absent on $\mathrm{CD} 44^{+} \mathrm{CD} 8 \alpha^{-}$ thymocytes (see Additional file 4), our data give hints to speculate that this molecule is up-regulated on naïve $\mathrm{T}$ helper cells after maturation in the thymus. Thus, CD8 $\alpha^{-}$ $\mathrm{CD}^{2} 7^{+} \mathrm{CD} 45 \mathrm{RC}^{-} \mathrm{SLA}-\mathrm{DR}^{-}$cells may represent recent thymic emigrants which have been described in human and mouse [28]. This hypothesis is supported by data from a time course study in piglets, where $\mathrm{T}$ helper cells from blood were analysed from birth to six month of age. In this study, a small proportion of CD8 $\alpha^{-}$CD $45 \mathrm{RC}^{-} \mathrm{SLA}^{-} \mathrm{DR}^{-} \mathrm{T}$ helper cells in blood was already detected at the day of birth [29].

$\mathrm{CD}^{2} \alpha^{+} \mathrm{CD} 27^{+} \mathrm{T}$ helper cells showed overall a CD45RC SLA-DR ${ }^{-}$phenotype within blood and secondary lymphatic 
organs (Figure 1b, contour plot series "Ib", Figure 2, light green population). By contrast, $\mathrm{CD} 8 \alpha^{+} \mathrm{CD} 27^{-} \mathrm{T}$ helper cells demonstrated a very heterogeneous expression for the CD45RC molecule and the majority of these cells were SLA-DR ${ }^{+}$in blood and liver. However, similar to their $\mathrm{CD}_{2} 7^{+}$counterparts, $\mathrm{CD} 8 \alpha^{+} \mathrm{CD} 27^{-} \mathrm{T}$ helper cells were mostly CD45RC'SLA-DR' in secondary lymphatic organs (Figure 1b, contour plot series and "Ic", Figure 2, ochre yellow population). Therefore, $\mathrm{CD} 8 \alpha^{+} \mathrm{CD} 27^{-} \mathrm{SLA}^{-} \mathrm{DR}^{+} \mathrm{T}$ helper cells were most prominent in locations that do not require entry via high endothelial venules but can be accessed by late effector cells. Thus, it is conceivable that SLA-DR expression on $\mathrm{CD} 8 \alpha^{+} \mathrm{CD} 27^{-} \mathrm{T}$ helper cells identifies terminally differentiated effector memory cells in swine. For CD45RC expression, a correlation towards differentiation in $\mathrm{CD} 8 \alpha^{+} \mathrm{T}$ helper cells is more difficult. In human CD27 CD45RA- effector memory $\mathrm{T}$ helper cells can reexpress CD45RA (CD27 CD45RA ${ }^{+} \mathrm{T}_{\mathrm{EMRA}}$ cells) which show multifunctional $\mathrm{T}$-cell responses to cytomegalovirus infection [30]. Featuring telomere-independent senescence, $\mathrm{T}_{\mathrm{EMRA}}$ cells especially accumulate in older human patients with persistent viral infections or inflammatory diseases [9,31]. By assuming a similar expression of CD45RA and CD45RC in pigs, one may speculate that $\mathrm{CD} 8 \alpha^{+} \mathrm{CD} 27^{-}$ $\mathrm{CD}_{45 \mathrm{RC}^{+}} \mathrm{T}$ helper cells represent a $\mathrm{T}_{\mathrm{EMRA}}$-like population.

In this study, we could also observe a small CD8 $\alpha^{-}$ CD27 subpopulation of porcine $\mathrm{T}$ helper cells which was most prominent in the liver. Considering also the highly reduced frequency of $\mathrm{CD} 8 \alpha^{+} \mathrm{CD} 27^{+}$cells in this organ, it might be conceivable, that apart from naive cells present in blood vessels draining the liver, only effector cells with appropriate chemokine receptor and adhesion molecule expression can enter the liver. Therefore, the $\mathrm{CD} 8 \alpha^{-} \mathrm{CD} 27^{-}$subpopulation might represent exhausted terminal effector cells which down-regulated CD8 $\alpha$ expression. In human T cells, CD27 ligation induces a strong up-regulation of anti-apoptotic molecules such as Bcl-xL and Bcl-2 which promote survival of activated effector cells [32,33]. In this context, analyses of antiapoptotic markers should give further information about distinct T-helper cell subsets in regard to their differentiation stage, including the $\mathrm{CD} 4^{+} \mathrm{CD} 8 \alpha^{-} \mathrm{CD} 27^{-}$phenotype.

In line with previous data, only $\mathrm{CD} 8 \alpha^{+} \mathrm{T}$ helper cells produced IFN- $\gamma$ after polyclonal stimulation as well as after PRRSV and FLUAVsw restimulation in vitro. Thereby, our study provides further evidence for an activation/memory stage of these cells $[3,4,6]$. With regard to CD27 expression, PMA/Ionomycin stimulation induced IFN- $\gamma$ release in both $\mathrm{CD} 27^{+}$and $\mathrm{CD} 27^{-} \mathrm{T}$ helper cells. Somewhat in contrast, more $\mathrm{CD} 27^{+} \mathrm{T}$ helper cells responded to recall stimulation with PRRSV and FLUAVsw. In terms of CD45RC expression, we observed high heterogeneity within IFN $-\gamma^{+} \mathrm{CD}^{+} \mathrm{T}$ cells for FLUAVsw, whereas more $\mathrm{CD}_{45 \mathrm{RC}^{-}}$cells responded to PRRSV and PMA/Ionomycin stimulation (Figure 3). In human, $\mathrm{CD}^{+}{ }^{+}$T-cell differentiation can be characterized by expression of markers as CD45RA, CCR7, CD27 and CD28 resulting in a diversity of T-helper cell subsets [9]. Several viral infections such as influenza virus, hepatitis $C$ virus, human immunodeficiency virus, and Epstein-Barr virus infection lead to antigenspecific $\mathrm{T}$ helper cells with different phenotypic profiles, but the majority display a central memory phenotype and express CD27 [34-37]. This is in accordance to the IFN- $\gamma^{+}$ $\mathrm{CD} 27^{+}$phenotype observed in this study following viral restimulation. Whether this means that $\mathrm{CD} 8 \alpha^{+} \mathrm{CD} 27^{+}$cells form the major pool of memory cells following FLUAVsw and PRRSV infection or that cells with this phenotype are more adapted to an in vitro restimulation environment, requires further investigations.

Nevertheless, in the present study, we could demonstrate that CD27 expression discriminates three functionally distinct T-helper cell subsets (Figures 4 and 5). In accordance with human data [38], our investigations of sorted $\mathrm{CD}^{+} \mathrm{T}$ cells revealed that $\mathrm{CD} 8 \alpha^{-} \mathrm{CD} 27^{+}$naïve $\mathrm{T}$ helper cells produced primarily IL- 2 but only reduced amounts of IFN- $\gamma$ and TNF- $\alpha$. In consideration of the rapid up-regulation of the CD $8 \alpha$ molecule, these cells might have already achieved an early differentiation state at which they were polarized for effector functions, similar to proliferating human naïve $\mathrm{CD}^{+}{ }^{+} \mathrm{T}$ cells $[20,39]$. In human $\mathrm{T}$ helper cells, the $\mathrm{CD} 27^{+}$memory population demonstrates a higher proliferative response than the naïve population [26]. In swine no apparent differences for proliferation between the $\mathrm{CD} 27^{+}$naive and activated subsets were observed. Furthermore, CD $8 \alpha^{+} \mathrm{CD} 27^{+} \mathrm{T}$ helper cells showed overall an intermediate cytokine production compared to the other subpopulations, thus resembling human central memory $\mathrm{T}$ helper cells [8]. In regard to CD27 expression, only few cells down-regulated CD27 after four days of stimulation, although this has been described for human $\mathrm{CD} 27^{+} \mathrm{T}$ helper cells following in vitro stimulation with CD3 and PMA/Ionomycin [27]. One possible explanation is that in vitro a different cytokine milieu prevailed than in vivo and thus differentiation into effector cells did not occur due to the lack of appropriate polarizing cytokines such as IL-12 [20,40]. Similar to human effector memory $\mathrm{T}$ helper cells [8], porcine CD27 $\mathrm{T}$ helper cells displayed an exhausted proliferation capacity and secreted highest IFN- $\gamma$ and TNF- $\alpha$ levels.

Analyses of lymph node homing receptors (Figure 6) corroborated our hypothesis that $\mathrm{CD} 8 \alpha^{+} \mathrm{CD} 27^{+}$cells resemble central memory $\mathrm{T}$ helper cells, whereas $\mathrm{CD} 8 \alpha^{+} \mathrm{CD} 27^{-}$cells are in a more terminally differentiated state and comprise effector memory $\mathrm{T}$ helper cells as described for human [8,9]. Expression of CCR7 was confirmed on naïve as well as on the majority of $\mathrm{CD} \alpha^{+} \mathrm{CD} 27^{+} \mathrm{T}$ helper cells from blood. Furthermore, both subsets expressed high levels of CD62L mRNA 
transcripts, thus displaying a tropism towards lymph nodes. On the contrary, $\mathrm{CD} 8 \alpha^{+} \mathrm{CD} 27^{-} \mathrm{T}$ helper cells from blood were divided into $\mathrm{CCR}^{+}$and $\mathrm{CCR}^{-}$subsets which showed little CD62L mRNA expression, indicating their improved ability to migrate into peripheral tissues. Of note, in human PBMCs, CD27 T helper cells are enriched in the CCR7 population [41] and differentiation of $\mathrm{T}$ helper cells is delineated from a CD2 $7^{+} \mathrm{CCR} 7^{+}$to a CD $27^{+} \mathrm{CCR}^{-}$and a CD27 ${ }^{-} \mathrm{CCR} 7^{-}$phenotype $[9,42]$. Similarly, in spleen and lymph nodes, we identified naïve $\mathrm{CD} 8 \alpha^{-} \mathrm{CCR}^{+} \mathrm{T}$ helper cells and the majority of $\mathrm{CD} 8 \alpha^{+}$cells were CCR7 ${ }^{-}$, regardless of the $\mathrm{CD} 27$ phenotype. However, in PBMCs nearly all $\mathrm{CD} 8 \alpha^{+} \mathrm{CD} 27^{+} \mathrm{T}$ helper cells expressed CCR7 and only within $\mathrm{CD} 8 \alpha^{+} \mathrm{CD} 27^{-}$cells a CCR7 $^{-}$population was present. Therefore, although it was only observed for porcine $\mathrm{T}$ helper cells from blood, CCR7 might be down-regulated during a later time point of differentiation than CD27.

Lastly, we identified highest mRNA levels of the fractalkine receptor $\mathrm{CX} 3 \mathrm{CR} 1$ in the $\mathrm{CD} 8 \alpha^{+} \mathrm{CD} 27^{-} \mathrm{T}$-helper cell subset. This is in accordance with data from human $\mathrm{T}$ helper cells, where protein expression of CX3CR1 was found in CD45RA'CD27 and CD45RO ${ }^{+} \mathrm{HLA}^{-} \mathrm{DR}^{+} \mathrm{T}$ helper cells [22,43].

In conclusion, our data provide novel insights into porcine T-helper cell differentiation. We could demonstrate that CD27 is a useful marker for discrimination of functionally distinct $\mathrm{T}$-helper cell subsets in swine. Overall, the properties of $\mathrm{CD} 27^{+}$and $\mathrm{CD} 27^{-}$porcine memory $\mathrm{T}$ helper cells closely resemble function and phenotype of human central memory and effector memory cells, respectively.

\section{Additional files}

\section{Additional file 1: Optimization and validation of qPCR for CD62L}

and CX3CR1. The suitability of the newly designed primers was verified as follows: For CX3CR1 a CDNA pool derived from a set of stimulated (PMA/lonomycin 6 h, ConA 12 h, and IL2/IL12/LL18 6 h) and unstimulated $(6 \mathrm{~h}, 12 \mathrm{~h})$ total PBMCs was tested in a 1:2 dilution series. For CD62L a 1:10 dilution series of the PCR products was performed. The dilution series, in conjunction with the melt characteristics of the PCR product, were used to optimize the assays regarding the primer concentration as well as the annealing and extension times for the PCR. The resulting slope of the regression analysis corresponding to the efficiency of the QPCR as well as the dynamic range for detecting 100\% positive of the lowest dilution are indicated. Calibration curve, melt curve and amplification plot for CD62L and CX3CR1 are depicted.

Additional file 2: Time course study of IFN- $\gamma$, TNF- $\alpha$ and IL-2 production in CD27-sorted T helper cells. Supernatants of FACS-sorted and ConA/rhlL-2 stimulated $\mathrm{CD} 4^{+} \mathrm{CD} 8 \mathrm{a}^{-} \mathrm{CD} 27^{+}$(naïve), $\mathrm{CD} 4^{+} \mathrm{CD} 8 \mathrm{a}^{+} \mathrm{CD} 27^{+}$ $\left(\mathrm{CD} 27^{+}\right)$and $\mathrm{CD}^{+}{ }^{+} \mathrm{CD} 8 \mathrm{a}^{+} \mathrm{CD} 27^{-}\left(\mathrm{CD} 27^{\circ}\right)$ cells were collected on day 1, 2 and 4 for ELISAs. The graphs show duration of cultivation on $x$-axes and mean values for the respective cytokine of duplicate wells in $\mathrm{ng} / \mathrm{mL}$ on $y$-axes. Results of one animal are depicted.

Additional file 3: Binding region of anti-CCR7 mAb. Alignment of full length CCR7 amino acid sequences of human, cattle and pig using GeneDoc Version 2.7.000 [44]. Sequences are derived from Gene Bank by
BLAST analyses and homologies are obtained from UniGene (NCBI). Based on the human CCR7 sequence (P32248 [CCR7_HUMAN] reviewed, UniProtKB/Swiss-Prot), the signal peptide (grey), the extracellular (yellow), and cytoplasmic (turquois) domains are highlighted. The red box indicates the binding region of anti-CCR7 mAb 3D12 (BD Biosciences).

Additional file 4: CD45RC expression on thymocytes. CD45RC expression (histograms) was analysed within four different subpopulations: $\mathrm{CD} 44^{-} \mathrm{CD} 8 \mathrm{a}^{-}, \mathrm{CD}^{+}{ }^{+} \mathrm{CD} 8 \mathrm{a}^{+}, \mathrm{CD}_{4}^{-} \mathrm{CD} 8 \mathrm{a}^{+}$and $\mathrm{CD} 4^{+} \mathrm{CD} 8 \mathrm{a}^{-}$ thymocytes (gates shown on contour plot) by FCM including a live/death discrimination dye. Data of one representative animal out of six is shown. At least $1 \times 10^{5}$ cells per sample were acquired.

\section{Abbreviations}

APCs: Antigen presenting cells; cDNA: Complementary DNA;

ConA: Concanavalin A; FACS: Fluorescence activated cell sorting; FCM: Flow cytometry; FITC: Fluorescein isothiocyanate; FLUAVsw: Swine Influenza A virus; IS: Internal standard; mAbs: Monoclonal antibodies; NTCs: No-template controls; PBMCs: Peripheral blood mononuclear cells; PE: Phycoerythrin; PMA: Phorbol myristate acetate; PRRSV: Porcine reproductive and respiratory syndrome virus; rhlL-2: Recombinant human IL-2; RT-qPCR: Reverse transcription quantitative polymerase chain reaction; SLA-DR: Swine leukocyte antigen-DR; TNFR: Tumor necrosis factor receptor.

\section{Competing interests}

The authors declare that they have no competing interests.

\section{Authors' contributions}

KR, WG and AS conceived and designed experiments. KR performed experiments. AM, SEE and JCD carried out RT-qPCR analyses. JL and PS helped with additional experiments. AL and MR coordinated the animal experiments. KR and WG wrote the paper. All authors critically revised the manuscript and approved the final version.

\section{Acknowledgments}

The authors thank Maria Stadler, Sandra Groiß, Anna Ondracek and Friedericke Steudle for general technical support, Miriam Viehmann, Eva Klingler, Hanna Koinig and Robert Graage for sampling and clinical monitoring of the animal experiments, Dr. Bernadette Glatthaar-Saalmüller for PRRSV propagation, Dr Ralf Dürrwald for providing Influenza A virus/ swine/Kitzen/IDT6142/2007, and Oswald Theurer for providing tissue and blood samples. Katharina Reutner was funded by the Comet programme "Preventive veterinary medicine: Improving pig health for safe pork production" sponsored by BMVIT, BMWFJ and the government of Lower Austria.

\section{Author details}

Institute of Immunology, Department of Pathobiology, University of Veterinary Medicine Vienna, Veterinärplatz 1, Vienna 1210, Austria. ${ }^{2}$ Institute of Immunology, Center for Pathophysiology, Infectiology and Immunology, Medical University of Vienna, Borschkegasse 8a, Vienna 1090, Austria. ${ }^{3}$ Institute for Medical Biochemistry, Department of Biomedical Sciences, University of Veterinary Medicine Vienna, Veterinärplatz 1, Vienna 1210, Austria. ${ }^{4}$ Clinic for Swine, Department for Farm Animals and Veterinary Public Health, University of Veterinary Medicine Vienna, Veterinärplatz 1, Vienna 1210, Austria.

Received: 16 November 2012 Accepted: 14 February 2013 Published: 11 March 2013

\section{References}

1. Saalmüller A, Reddehase MJ, Bühring HJ, Jonjic S, Koszinowski UH: Simultaneous expression of CD4 and CD8 antigens by a substantial proportion of resting porcine T lymphocytes. Eur J Immunol 1987, 17:1297-1301

2. Pescovitz MD, Sakopoulos AG, Gaddy JA, Husmann RJ, Zuckermann FA: Porcine peripheral blood CD4+/CD8+ dual expressing T-cells. Vet Immunol Immunopathol 1994, 43:53-62.

3. Saalmüller $A$, Werner $T$, Fachinger $V$ : T-helper cells from naïve to committed. Vet Immunol Immunopathol 2002, 87:137-145. 
4. Summerfield A, Rziha HJ, Saalmüller A: Functional characterization of porcine $\mathrm{CD}^{+} \mathrm{CD}^{+}$extrathymic T lymphocytes. Cell Immunol 1996, 168:291-296.

5. Zuckermann FA, Husmann RJ: Functional and phenotypic analysis of porcine peripheral blood CD4/CD8 double-positive T cells. Immunology 1996, 87:500-512.

6. Gerner W, Denyer MS, Takamatsu HH, Wileman TE, Wiesmüller KH, Pfaff E, Saalmüller A: Identification of novel food-and-mouth disease virus specific T-cell epitopes in $\mathrm{c} / \mathrm{c}$ and $\mathrm{d} / \mathrm{d}$ haplotype miniature swine. Virus Res 2006, 121:223-228.

7. Gerner W, Käser T, Saalmüller A: Porcine T lymphocytes and NK cells - an update. Dev Comp Immunol 2009, 33:310-320.

8. Sallusto F, Lenig D, Förster R, Lipp M, Lanzavecchia A: Two subsets of memory T lymphocytes with distinct homing potentials and effector functions. Nature 1999, 401:708-712.

9. Appay V, Van Lier RAW, Sallusto F, Roederer M: Phenotype and function of human T lymphocyte subsets: consensus and issues. Cytometry A 2008, 73A:975-983.

10. Nolte MA, Van Olffen RW, Van Gisbergen KPJM, Van Lier RAW: Timing and tuning of CD27-CD70 interactions: the impact of signal strength in setting the balance between adaptive responses and immunopathology. Immunol Rev 2009, 229:216-231.

11. Reutner K, Leitner J, Essler S, Witter K, Patzl M, Steinberger P, Saalmüller A, Gerner W: Porcine CD27: identification, expression and functional aspects in lymphocyte subsets in Swine. Dev Comp Immunol 2012, 38:321-331.

12. Crispe IN: Isolation of mouse intrahepatic lymphocytes. In Current protocols in immunology. Edited by Coligan JE, Bierer BE, Margulies $\mathrm{DH}$ Shevach EM, Stober W. Somerset NJ: John Wiley \& Sons Inc; 2001. Unit 3.21.

13. Leitner J, Reutner K, Essler SE, Popow I, Gerner W, Steinberger P, Saalmüller A: Porcine SWC1 is CD52 - final determination by use of a retroviral cDNA expression library. Vet Immunol Immunopathol 2012, 146:27-34.

14. Saalmüller $A$ : Characterization of swine leukocyte differentiation antigens. Immunol Today 1996, 17:352-354

15. Gerner W, Käser T, Pintarič M, Groiß S, Saalmüller A: Detection of intracellular antigens in porcine PBMC by flow cytometry: a comparison of fixation and permeabilisation reagents. Vet Immunol Immunopathol 2008, 121:251-259.

16. Käser T, Müllebner A, Hartl RT, Essler SE, Saalmüller A, Duvigneau JC: Porcine T-helper and regulatory $T$ cells exhibit versatile mRNA expression capabilities for cytokines and co-stimulatory molecules. Cytokine 2012, 60:400-409.

17. Rozen S, Skaletsky H: Primer3 on the WWW for general users and for biologist programmers. Methods Mol Biol 2000, 132:365-386.

18. Ye J, Coulouris G, Zaretskaya I, Cutcutache I, Rozen S, Madden TL: PrimerBLAST: a tool to design target-specific primers for polymerase chain reaction. BMC Bioinformatics 2012, 13:134-144

19. Duvigneau JC, Hartl RT, Groiss S, Gemeiner M: Quantitative simultaneous multiplex real-time PCR for the detection of porcine cytokines. J Immunol Methods 2005, 306:16-27.

20. Pepper $\mathrm{M}$, Jenkins MK: Origins of $\mathrm{CD}^{+}$effector and central memory $\mathrm{T}$ cells. Nat Rev Immunol 2011, 12:467-471.

21. Vrieling M, Santema W, Van Rhijn I, Rutten $V$, Koets $A$ : $\gamma \delta T$ cell homing to skin and migration to skin-draining lymph nodes is CCR7 independent. $\mathrm{J}$ Immunol 2012, 188:578-584.

22. Nishimura M, Umehara H, Nakayama T, Yoneda O, Hieshima K, Kakizaki M, Dohmae N, Yoshie O, Imai T: Dual functions of fractalkine/CX3C ligand 1 in trafficking of perforin ${ }^{+} / g$ ranzyme $\mathrm{B}^{+}$cytotoxic effector lymphocytes that are defined by CX3CR1 expression. J Immunol 2002, 168:6173-6180.

23. Ober BT, Summerfield A, Mattlinger C, Wiesmüller $\mathrm{KH}$, Jung $\mathrm{G}$, Pfaff $E$, Saalmüller A, Rziha HJ: Vaccine-induced, pseudorabies-specific, extrathymic $\mathrm{CD}^{+}{ }^{+} \mathrm{CD} 8^{+}$memory T-helper cells in swine. J Virol 1998, 72:4866-4873.

24. Revilla C, Rodríguez-Carreno MP, Alvarez B, Chamorro S, Alonso LM, Ezquerra A Alonso F, Domínguez J: 2E3, a new marker that selectively identifies porcine CD4 ${ }^{+}$naïve T cells. Dev Comp Immunol 2004, 28:239-250.

25. Revilla C, Chamorro S, Alvarez B, Perez C, Ezquerra A, Alonso F, Dominguez $\mathrm{J}$ : Analysis of functional heterogeneity of porcine memory $\mathrm{CD}^{+} \mathrm{T}$ cells. Dev Comp Immunol 2005, 29:479-488.

26. Schiött $A$, Lindstedt $M$, Johansson-Lindbom B, Roggen $E$, Borrebaeck CAK: $\mathrm{CD} 27^{-} \mathrm{CD} 4^{+}$memory $\mathrm{T}$ cells define a differentiated memory population at both the functional and transcriptional levels. Immunology 2004, 113:363-370.
27. Fritsch RD, Shen X, Sims GP, Hathcock KS, Hodes RJ, Lipsky PE: Stepwise differentiation of CD4 memory T cells defined by expression of CCR7 and CD27. J Immunol 2005, 175:6489-6497.

28. Fink PJ, Hendricks DW: Post-thymic maturation: young T cells assert their individuality. Nat Rev Immunol 2011, 11:544-549.

29. Talker SC, Käser T, Reutner K, Sedlak C, Mair KH, Koinig H, Graage R, Viehmann M, Klingler E, Ladinig A, Ritzmann M, Saalmüller A, Gerner W: Phenotypic maturation of porcine NK- and T-cell subsets. Dev Comp Immunol 2013, 40:51-68.

30. Libri V, Azevedo RI, Jackson SE, Di Mitri D, Lachmann R, Fuhrmann S, Vukmanovic-Stejic M, Yong K, Battistini L, Kern F, Soares MV, Akbar AN: Cytomegalovirus infection induces the accumulation of short-lived, multifunctional $\mathrm{CD} 4{ }^{+} \mathrm{CD} 45 \mathrm{RA}^{+} \mathrm{CD} 27^{+} \mathrm{T}$ cells: the potential involvement of interleukin-7 in this process. Immunology 2011, 132:326-339.

31. Di Mitri D, Azevedo RI, Henson SM, Libri V, Riddell NE, Macaulay R, Kipling D, Soares MVD, Battistini L, Akbar AN: Reversible senescence in human CD4 ${ }^{+}$CD45RA $^{+}$CD27 memory T cells. J Immunol 2011, 187:2093-2100.

32. Rogers PR, Song J, Gramaglia I, Killeen N, Croft M: OX40 promotes BCl-xL and $\mathrm{BCl}-2$ expression and is essential for long-term survival of CD4 T cells. Immunity 2001, 15:445-455.

33. Van Oosterwijk MF, Juwana $H$, Arens $R$, Tesselaar $K$, Van Oers MHJ, Eldering E, Van Lier RAW: CD27-CD70 interactions sensitise naive CD4 $^{+} \mathrm{T}$ cells for IL-12-induced $\mathrm{T}_{\mathrm{h}} 1$ cell development. Int Immunol 2007, 19:713-718.

34. Amyes E, Hatton C, Montamat-Sicotte D, Gudgeon N, Rickinson AB, MC Michael AJ, Callan MFC: Characterization of the $\mathrm{CD}^{+} \mathrm{T}$ cell response to Epstein-Barr virus during primary and persistent infection. J Exp Med 2009, 198:903-911.

35. Day CL, Seth NP, Lucas M, Appel H, Gauthier L, Lauer GM, Robbins GK Szczepiorkowski ZM, Casson DR, Chung RT, Bell S, Hartcourt G, Walker BD, Klenerman $P$, Wucherpfennig KW: Ex vivo analysis of human memory CD4 T cell specific for hepatitis C virus using MHC class II tetramers. J Clin Invest 2003, 112:831-842

36. Lucas M, Day CL, Wyer JR, Cunliffe SL, Loughry A, McMichael AJ, Klenerman $P$ : Ex vivo phenotype and frequency of influenza virus-specific CD4 memory T cells. J Virol 2004, 78:7284-7287.

37. Yue FY, Kovacs CM, Dimayuga RC, Parks P, Ostrowski MA: HIV-1 specific memory $\mathrm{CD}^{+} \mathrm{T}$ cells are phenotypically less mature than cytomegalovirus-specific memory CD4 ${ }^{+}$T cells. J Immunol 2004, 172:2476-2486.

38. Wang $X$, Mosmann T: In vivo priming of CD4 T cells that produce interleukin (IL)- 2 but not IL-4 or interferon (IFN)- $\gamma$, and can subsequently differentiate into IL-4 or IFN- $\gamma$-secreting cells. J Exp Med 2001, 194:1069-1080.

39. Seder RA, Ahmed R: Similarities and differences in $\mathrm{CD}^{+}$and $\mathrm{CD} 8^{+}$ effector and memory T cell generation. Nat Rev Immunol 2003, 4:835-842.

40. Zhou L, Chong MMW, Littman DR: Plasticity of $\mathrm{CD}^{+} \mathrm{T}$ cell lineage differentiation. Immunity Rev 2009, 30:646-655.

41. Campbell JJ, Murphy KE, Kunkel EJ, Brightling CE, Soler D, Shen Z, Boisvert J, Greenberg HB, Vierra MA, Goodman SB, Genovese MC, Wardlaw AJ, Butcher EC, Wu L: CCR7 expression and memory T cell diversity in humans. $\mathrm{J}$ Immunol 2001, 166:877-884

42. Yang Y, An J, Weng NP: Telomerase is involved in IL-7-mediated differential survival of naïve and memory CD4 ${ }^{+}$T cells. J Immunol 2008, 180:3775-3781.

43. Foussat A, Coulomb-L'Hermine A, Gosling J, Krzysiek R, Durand-Gasselin I, Schall T, Balian A, Richard Y, Galanaud P, Emilie D: Fractalkine receptor expression by $\mathrm{T}$ lymphocyte subpopulations and in vivo production of fractalkine in human. Eur J Immunol 2000, 30:87-97.

44. Nicholas KB, Nicholas HB Jr, Deerfield DW II: GeneDoc: analysis and visualization of genetic variation. EMBNEW NEWS 1997, 4:14.

\section{doi:10.1186/1297-9716-44-18}

Cite this article as: Reutner et al:: CD27 expression discriminates porcine $\mathrm{T}$ helper cells with functionally distinct properties. Veterinary Research 2013 44:18. 